\title{
Role of Reactive Sintering in Production of Technically Important Intermetallics
}

Pavel Novák, Jan Kříž, Alena Michalcová, Pavel Salvetr

University of Chemistry and Technology, Prague, Department of Metals and Corrosion Engineering, Technická 5, 166 28 Prague 6, Czech Republic, E-mail: panovak@vscht.cz, krizj@vscht.cz, michalca@vscht.cz, salvetrp@vscht.cz

Intermetallics offer many interesting properties, such as excellent resistance against high-temperature oxidation and creep, special magnetic properties, shape memory or the ability of reversible hydrogen storage. For these reasons, intermetallics are considered as very promising materials for many modern applications in power generation, automotive or aerospace industry and also in the medicine. The factors limiting their wider use are low room-temperature toughness and problems with their production. In this work, the possibilities of the use of powder metallurgy using reactive sintering for the production of intermetallics for medicine (Ni-Ti alloys) and for high-temperature applications (aluminides, silicides) are presented. The effect of process parameters on the proceeding reactions and structure of obtained materials is discussed.

Keywords: powder metalurgy, reactive sintering, intermetallics

\section{Acknowledgement}

This research was financially supported by the Czech Science Foundation, project No. 14-03044S.

\section{References}

[1] ŠÍMA, V., KRATOCHVÍL, P., KOZELSKÝ, P., SCHINDLER, I., HÁNA, P. (2009). In: International Journal of Materials Research, Vol. 100, pp. 382-385. Hanser Verlag, Germany.

[2] J. BARBOSA, C. SILVA RIBEIRO, A. CAETANO MONTEIRO (2007). Influence of superheating on casting of $\gamma$-TiAl. In: Intermetallics, Vol. 15, pp. 945-955. Elsevier. Netherlands.

[3] SCHINDLER, I., KRATOCHVÍL, P., PROKOPČÁKOVÁ, P., KOZELSKÝ, P. (2005). Forming of cast Fe - 45 at.\% Al alloy with high content of carbon. In: Intermetallics 18 (2010) 745-747. Elsevier. Netherlands.

[4] NOVÁK, P., VODĚROVÁ, M., HENDRYCH, R., KUBATÍK, T., MICHALCOVÁ, A., VOJTĚCH, D. (2013). Preparation of aluminium-based quasicrystals. In: Manufacturing Technology, Vol. 13, No. 3, pp. 390-394. UJEP. Czech Republic.

[5] ALMAN, D. E. (2005). Reactive sintering of TiAl-Tis $\mathrm{Si}_{3}$ in situ composites, In: Intermetallics, Vol. 13, pp. 572579. Elsevier. Netherlands.

[6] NOVÁK, P., VOJTĚCH, D., ŠERÁK, J. (2006). Wear and corrosion resistance of a plasma-nitrided PM tool steel alloyed with niobium. In: Surface and Coatings Technology, Vol. 200, pp. 5229 - 5236. Elsevier. Netherlands.

[7] JOZWIAK, S., KARCZEWSKI, K., BOJAR, Z. (2010). Kinetics of reactions in FeAl synthesis studied by the DTA technique and JMA model. In: Intermetallics, Vol. 18, pp. 1332-1337. Elsevier. Netherlands.

[8] NOVÁK, P., MICHALCOVÁ, A. MAREK, I., VODĚROVÁ, M., VOJTĚCH, D. (2012). Possibilities of the observation of chemical reactions during the preparation of intermetallics by reactive sintering. In: Manufacturing Technology, Vol. 12, No. 13, pp. 197-201. UJEP. Czech Republic.

[9] NOVÁK, P. KNOTEK, V., VODĚrOVÁ, M., KUBÁSEK, J., ŠERÁK, J., MICHALCOVÁ, A., VOJTĚCH, D. (2010). Intermediary phases formation in $\mathrm{Fe}-\mathrm{Al}-\mathrm{Si}$ alloys during reactive sintering. In: Journal of Alloys and Compounds, Vol. 497, pp. 90-94. Elsevier. Netherlands.

[10] VOJTĚCH, D., KUBÁSEK, J., NOVÁK, P. (2013). Corrosion properties of the superelastic shape memory Ni-Ti alloy for medical implants. In: Manufacturing Technology, Vol. 13, No. 3, pp. 409-414. UJEP. Czech Republic.

[11] NOVÁK P., ŠKOLÁKOVÁ A., VOJTĚCH V., KNAISLOVÁ A., POKORNÝ P., MORAVEC H., KOPEČEK J., KARLÍK M., KUBATÍK T.F. (2014). Application of Microscopy and X-ray Diffraction in Optimization of the Production of NiTi Alloy by Powder Metallurgy. In: Manufacturing Technology, Vol. 14, pp. 387-392. 